Georg Zipp*

\title{
Selling Poverty: Junot Díaz's and Edwidge Danticat's Assessments of Picturesque Stereotypes of Poverty in the Caribbean
}

\begin{abstract}
Taking the topos of the Caribbean as paradise as point of departure, this article analyses how Edwidge Danticat's Claire of the Sea Light and Junot Díaz's The Brief Wondrous Life of Oscar Wao re-write the stereotype of the paradisiacal and picturesque islands. This entails that literary texts and novels, as a form of armchair tourism, potentially offer a form of engagement with poverty in which the voyeuristic gaze can be deflected. Complex literary texts can be a 'safer' form of exploring, vicariously experiencing, and thinking about poverty.
\end{abstract}

\section{Selling Poverty}

According to John Lanchester, wealth, albeit a fuzzy term, "refers to accumulated assets rather than to earnings. Rich people are wealthy, by definition, but you can be wealthy without being, in practical terms, rich," for example, when one is living in a mansion but is "short of usable cash" (Lanchester 2014, 244). In a Caribbean context, this means that Caribbean societies generally are wealthy - in that they dispose of concrete or abstract natural resources - e.g., oil, in the case of Trinidad, or picturesque landscapes, in the case of all other islands - but a failure to sustainably convert these assets into money and hence a certain standard of living means that a wealthy region can be poor too. Closely connoted with the idea of wealth and luxury is that of paradise, and there is a long tradition of depicting the Caribbean as such; paradise is probably the short-hand of what the Caribbean stands for in the global imaginary: Ian Gregory Strachan has investigated how the myth of the Caribbean as paradise has evolved throughout history and how it has been inextricably intertwined with the plantation economy and the development of global capitalism (Strachan 2002). Moreover, for ideological reasons, in

*Corresponding author: Georg Zipp, English Department, University of Freiburg, 79085 Freiburg i. Br., Germany, e-mail: georg.zipp@neptun.uni-freiburg.de 
the early days of tourism in the Caribbean, notions of both paradise and, even if seemingly paradoxically, plantation life came to be framed as picturesque (Thompson 2006, 1-43). Natural beauty and the promise of luxury have therefore long been the assets of the Caribbean tourist's dream, and - albeit clichéd - are part of the global social imaginary.

In a review essay Richard J. Powell calls this phenomenon "tropicalization," which

renders every town or vista within its viewfinder as a generic paradise. Despite the geological peculiarities or demographic realities of a given place, the Caribbean that exists in the tropicalizing eye is abundant with just-plucked-from-the-vine delicacies, free from metropolitan influences (yet completely equipped with modern amenities), discreetly tolerant of sybaritic pleasures and, whether colonial or corporate, always under the God-like dominion of the authorities. (Powell 2008, 160)

Whereas the tourist industry in earlier decades tried to pitch this image of paradise on Earth, and real estate developers were keen to build roads in such a way that tourists would be shielded from any social misery (Handley and Walcott 2005, 134), today slum tourism is a booming segment of the market: in cities all over the world there are guided tours in which tourists are invited to experience first-hand what life is supposedly like in a slum tenement. ${ }^{1}$

There is a conundrum in poverty as a 'natural resource' to be marketed to tourists: traditional natural assets are always in danger of being depleted beautiful beaches, for example, are endangered by property development and pollution - so the question of how to generate money from that whose shrinking is always present. When poverty becomes a natural resource to be marketed to tourists then the question is turned upside down: how to shrink that which is generating money but which is ostensibly being eliminated.

Slum tourism has its ambivalences; ${ }^{2}$ critical voices tend to emphasise that it is a social situation marked by an ethically precarious imbalance of power evident in acts of looking. Claire Williams has noted in relation to Brazilian favela literature:

1 For an overview over the boom of slum tourism and concomitant theories see Dürr and Jaffe (2012), for an attempt to frame the debate in more scholarly terms, see Selinger and Outterson (2009).

$\mathbf{2}$ It might help raise awareness and generate income for a destitute community - whose members might then have to masquerade as poorer than they 'really' are in order to keep the tourists coming. Slum tourism can, of course, also be an instrument of self-empowerment. However, since a tourist's engagement with these communities usually involves a very short period of time, their engagement will often remain superficial, almost by definition preventing a sustained engagement. 
The tourist gaze may be romantic, spectatorial, reverential, anthropological, environmental or mediatised [...] but it always creates a subject-object structure or an artificial boundary. The gaze may be consciously or unconsciously voyeuristic and imply exploitation of the people and/or place being visited. (Williams 2008, 486)

'Slumming' has been criticised too in all forms of art, from pop music to poetry. Kobo Town's "Postcard Poverty" is an example of the former. The band is led by Trinidadian-Canadian singer-songwriter Drew Gonsalves. According to their website the band sees itself in an anti-colonial tradition, since their name is derived from a neighbourhood in Trinidad's capital Port-of-Spain, an area of "constant defiance and conflict, a place where sticks and stones, songs and verses clashed with the bayonets and batons of colonial rule." "Postcard Poverty" is a mocking take on a tourist's auto-fiction of having a supposedly 'authentic' experience: "With time to kill and money to spend//Come to slum down in the tenement” (Kobo Town 2013). The accompanying CD booklet stipulates that there are only two kinds of tourists: those "seeking clear blue waters and soft sandy beaches divorced from the communities and people they encircle," while others "seek in the crumbling squalor of our tenements the exotic backdrop to their holiday adventures." Consequently, the tourists in "Postcard Poverty" hope to accumulate cultural and social capital while spending money to get a good view of those without it: they are at liberty to move between rich and poor spaces, and for the visitors, the tenement is a temporary experience, almost a heterotopia. The song makes fun of the superficial, temporally limited engagement with a host culture, which the 'independent' traveller, while rejecting the role of the 'traditional' tourist, cannot escape:

Aiming up and down, pointing high and low

Digital camera shooting up the ghetto

They want snapshot sadness for the slideshow (Kobo Town 2013)

and arguably seek out only the confirmation of stereotypes and sensational stories of the other, of once having gone "down to the depths of hell//For a souvenir and a story to tell” (Kobo Town 2013). Looking for a fiction of a meaningful connection, of the status as a temporary insider, the tourist, "down with the brothers and not just a gringo," longs to become an 'ambassador' and interpreter:

Because he feels he's one of a kind

A Vasco de Gama looking for the first time

At a land unknown to his homebound friends

That only he can explain to them. (Kobo Town 2013)

For Kobo Town, both kinds of tourists - those seeking out landscapes removed from their social surroundings and those seeking out the squalor - exoticise 
and objectify the Caribbean. However, even with less prying tourists, the question arises how they can position themselves towards the poverty they see; this clash between relative and universal values is described in one of the first scenes of Diana McCaulay's 2010 novel Dog-Heart, where a confrontation takes place between a guard at a shopping plaza, who asserts that "Ghetto pickney must beat" and a woman, who, upon objecting to the guard's behaviour, is told by her husband that "they on holiday, don't know about things in Jamaica” (McCaulay 2010, 13).

From his early writings onward, Derek Walcott has been an authoritative critic of bystanders' desire to prettify poverty and to make it appear bucolic and picturesque:

[...] one walks past the gilded hallucinations of poverty with a corrupt resignation touched by details, as if the destitute, in their orange-tinted backyards, under their dusty trees, or climbing to their favelas, were all natural scene-designers and poverty were not a condition but an art. Deprivation is made lyrical, and twilight, with the patience of alchemy, almost transmutes despair into virtue. (Walcott 1971, 3)

However, this kind of "theatre," or fantasy-charged inner dramatisation, is "vivid, voluble and cheap" (Walcott 1971, 4): "the last thing which the poor needed was the idealisation of their poverty" - a mistake to which his own generation might have succumbed too (Walcott 1971, 19). ${ }^{3}$ In his Nobel speech, he famously remarked that for tourists, "in the unending summer of the tropics not even poverty or poetry (in the Antilles poverty is poetry with a V, une vie, a condition of life as well as of imagination) seems [...] profound because the nature around it is so exultant” (Walcott 1998, 72). In an interview in 2005, he revisits the point that natural beauty and poverty are deeply intertwined:

People who come to tour the Caribbean are going to tour a lot of poverty, and that's going to be visually and practically there. What is corrupt is if you exploit the picturesqueness of the poverty, and if you say, 'Well, the poorer scenes are better than the expensive-looking scenes.' [...] What's photogenic is to have a very poor, young, black kid in front of some terrific-looking shacks in great sunlight. Now that's the kind of whoring that you are talking about. (Handley and Walcott 2005, 137) ${ }^{4}$

3 Or, in Omeros: “[...] Didn't I want the poor//to stay in the same light so that I could transfix// them in amber, the afterglow of an empire, //preferring a shed of palm-thatch with tilted sticks// to that blue bus-stop?" (Walcott 1990, 227).

4 This is implied in Omeros in the verse "Philoctete smiles for the tourists, who try taking his soul with their cameras" (Walcott 1990, 3), which gently mocks the commonplace belief among tourists that some cultures disapprove of having their photos taken not for ethical but superstitious reasons. 
To Walcott, hiding poverty or merely prettifying it by turning it into a bucolic or picturesque representation is not a solution: In his view, tourists should be confronted with it, but he hopes that art can help to refine people's interpretation of what they see:

The other reality is that these places are picturesque, that they do look a particular way. I think that it is what illuminates them; when an artist illuminates them, then it becomes a different thing. Because now what you're looking at is not only the reality of poverty but something beyond it that the artist finds worth illuminating. (Handley and Walcott 2005, 138)

This ties in with his metaphor of the Caribbean as a broken vase, which has been glued back together: "Antillean art is this restoration of our shattered histories, our shards of vocabulary, our archipelago becoming a synonym for pieces broken off from the original continent" (Walcott 1998, 69). Walcott concludes from this that the creation of poetry - and by extension, one can follow, that of literature in general - is not a creative process without a starting point, it is always a "remaking," not just a “'making”" of poetry (Walcott 1998, 69). If reality cannot be put together seamlessly, then a bucolic, unified, blissful vision of poverty does not do justice to this fragmented experience of reality, and where already fraught with clichés and therefore problematic in a British narrative tradition (as discussed in Kumar 1995), it would be false in a Caribbean context.

\section{Encountering Poverty in Literary Texts}

I argue that literary texts and novels offer a form of armchair tourism, and a form of engagement with the poverty of a place, in which the voyeuristic gaze can be deflected. They can therefore be a 'safer' form of exploring, vicariously experiencing, and thinking about poverty. Literary visits to impoverished spaces can be ethically questionable, too, and especially so when that which is depicted tends to confirm sensationalist stereotypes rather than re-configuring readers' notions about poverty. ${ }^{5}$ This means that a text's ideology and its function within a broader literary system has to be taken into account. I am interested in the question of how the social and cultural imaginary on poverty is re-configured through

5 In a related study on poverty in Britain, Barbara Korte and I employ a figurations approach to analyse literary texts circulating on the British book market with regard to their presence in the popular imagination and how their respective literary genres confirm or destabilise stereotypical perceptions about poverty (Korte and Zipp 2014). 
individual literary texts: ${ }^{6}$ Poverty is not just part of the geographical landscape but also an important social and cultural faultline in the entire region, and one which takes many different forms, has many different causes, consequences, and contributing factors: I propose to scrutinise these texts for recurring motifs and topoi which are re-activated in the social imaginary, for the modes in which social misery is presented (e.g., naturalistic, humorist etc.), and for the causes and consequences of poverty which are postulated. In short: It is vital to ask what the ideology of a given text is, how it attempts to re-configure the social imaginary. As part of a broadly cultural materialist project, this inquiry has to include reading the context and modes of circulation of a text, but sometimes also reading it against itself.

The entire history of literature in the Anglophone Caribbean can be thought of as a history of thinking and writing about poverty. Eric Walrond's short story collection Tropic Death (1926) is not only one of the foundational texts of Caribbean literature itself: Walrond was also one of the first writers to note and de-construct the relationship between the picturesque and the poor in the Caribbean imaginary. According to Richard J. Powell, Walrond turns "a potentially picturesque (that is, saccharine) scenario into a series of tragic, imagistic vignettes" (Powell 2008, 163). As a result of Walrond's "meshing of the tropical with the 'antitropical,' he transforms Western romanticism about the Caribbean into a sociopolitical discourse" (Powell 2008, 164). The Caribbean writer's challenge has not changed much: it is not necessarily to exclude all things picturesque from their fiction, but rather to paint a more differentiated, and more complex picture. As I am going to show, Edwidge Danticat and Junot Díaz deploy several strategies to deflect the voyeuristic gaze of readers, who, in a global literary market place, are often also outsiders to the region. While they also show poverty as a matter of course, they mostly do so by strategically managing gaps and silences.

Claire of the Sea Light, the 2013 novel by Haitian-American writer Edwidge Danticat describes the story of Claire, ${ }^{7}$ who, upon hearing that she is to be given away by her father as a restavèk, disappears on the day of her birthday. The novel

6 In a broader research project, I concentrate on complex literary approaches to narrating poverty in the Caribbean. This comprises a historical overview over poverty writing in the Caribbean (ranging from CLR James, Ralph de Boissiere, Alfred Mendes, over Garth St Omer, George Lamming, Roger Mais, Orlando Patterson, Jamaica Kincaid, V.S. Naipaul to Kei Miller) and more detailed discussions of works by Achy Obejas, Junot Díaz, Edwidge Danticat as well as Diana McCauley.

7 The girl's full name is Claire Lymè Lanmè [lumière de la mer] Faustin, “Claire of the Sea Light.” She is named after her mother Claire and an abandoned lighthouse in the village (Danticat 2013, 35). The ambivalence of the symbol of the lighthouse is reflected in the fact that people die or disappear into the sea on her birthdays, which is a recurring theme throughout the novel. 
can also be read as a series of linked short stories; set at various points in the narrative present and the recent past of ten years ago, and focalised through different inhabitants of the town of Ville Rose, it presents a complex landscape, where, with significant events happening off-scene, the reader has to fill out gaps in the sequence of events in order to make sense of the entire story. This formal complexity is complemented by certain thematic elisions: in the novel, Danticat suspends history and the political arena from the Haitian landscape. Haiti is an imaginary space over-determined by ideology and outside intervention, illustrated by the clichéd moniker of 'the poorest country of the western hemisphere.' The 2010 earthquake, for example, becomes a gap itself, which, if represented, would eclipse most other factors that influence a life in poverty in Haiti. Danticat is known as a political writer and public persona; she has commented widely on current affairs. In this novel, however, her politics is evident in her exploration of poverty on the level of the experience of her individual characters, which is, of course, inseparable from the society that surrounds them. She represents poverty without idealising it as bucolic state of bliss but also avoids shifting the blame on merely structural forces. As in more conventional picturesque depictions of poverty, Danticat's imagery conveys that the poverty is part of the natural landscape:

Ville Rose was home to about eleven thousand people, five per cent of them wealthy or comfortable. The rest were poor, some dirt-poor [...] [T]he town had a flower-shaped perimeter that, from the mountains, looked like the unfurling petals of a massive tropical rose [...]. (Danticat 2013, 5)

On a meta-level, the novel also addresses the question of Danticat's legitimacy as an intermediary between Haiti and a global audience. Her writing - like that of Junot Díaz - circulates globally on the literary market place; they were published by transnational publishing houses, they have appeared in The New Yorker, were selected for television Book Clubs and have won literary prizes, all of which indicates a high visibility on the global literary market (cf. Korte and Zipp 2014). The time has passed when Jamaica Kincaid could be called "our sassy black friend" (Trow 1974, 31) but these publications still function, as Evelyn Hawthorne puts it, within a "hegemonic literary environment," and cater to an 'enlightened,' metropolitan audience, where anything coming from the margins becomes representative of the reality at the fringe (Hawthorne 2003, 3). Edwidge Danticat is aware of the ethical pitfalls of representing: in her 2010 essay collection Create Dangerously, she re-tells a scene in which family members refuse to tell her anything because people say that "'everything they say to you ends up written down somewhere." Danticat concedes that she, as an "immigrant artist, like all other artists, 
is a leech" (Danticat 2010, 94-95). It is central to her poetic project to collage her "own narratives with the oral and written narratives of others," with the result that "our stories are the bastard children of everything that we have ever experienced and read" (Danticat 2010, 62).

Danticat's status as a teichoscope, straddling two cultures, does not allow her to renounce the real: she aims for veracity in her fiction. The question of whether this is legitimate is addressed in her story "Ghosts," which is part of the novel Claire of the Sea Light and was published in slightly different form in the New Yorker: Bernard ${ }^{8}$, growing up in Cité Pendue, a "midlevel slum" (Danticat 2013, 63) extension of Ville Rose, wants to become a radio producer and make a radio programme on the gang children - called "chimè, chimeras or ghosts" (Danticat 2013, 65) - who terrorise the neighbourhood, which, for some people "the first region's circle of hell," should not be a terrible place to live since it disposes of "a few Protestant churches, many Vodou templs, some restaurants and bakeries, and even a couple of dry cleaners" (Danticat 2013, 63). As such it is characterised for the reader as a civilised human settlement, but features so obvious that they would normally not be mentioned in the context of a slum.

Bernard's family has profited economically from living in the neighbourhood and selling pigeons for a blood-thirsty ritual, but Bernard would like to raise awareness for the living conditions within the slum. He becomes wrongfully indicted, imprisoned and then released following the help from Tiye, ${ }^{9}$ the gang leader whom he was going to cover in his future radio programme, but, at the end of the story, finds himself at his mercy. Where the state's monopoly of violence is failing, the powerless gang leader is presented as the one actually in power; however, this only a fleeting, elusive sort of power resembling a Hobbesian natural state: one of the last paragraphs makes abundantly clear that Tiye will be dead before his time:

Bernard realized that this was all a game to Tiye. He had turned Bernard in, then rescued him, and now he was having a few laughs and some beers. It was all in a day's work. Still, Bernard couldn't shake the feeling that one day they would all be shot. Like the fabric shop owner Laurent Lavaud and like almost every young man living in the slums. One day it might occur to someone, someone angry and powerful, and maniacal - a police chief or a gang leader, or a leader of the nation - that they, and all those who lived near or like them, would be better off dead. (Danticat 2013, 80-81)

8 In the magazine version, Bernard's name is Pascal. In this analysis, he is referred to as Bernard throughout.

9 Tiye, just as his predecessor Piye, has a telling name: “The men of Baz Benin gave themselves the monikers of Nubian royalty, which also happened to suggest menacing acts in Creole - Piye, for example, meaning ‘to pillage,' Tiye, meaning ‘to kill’” (Danticat 2013, 63). 
This is in contrast with a lyrical passage describing Bernard's original ambition of giving the inhabitants of the slum a voice. The magazine version is almost identical but is even more emotional in its impact than the same passage in the novel (cf. Danticat 2013, 82):

\begin{abstract}
In his dreams, [Bernard] had imagined beginning his radio program with a segment on lost limbs. Not just Tiye's but other people's as well. He would open with a discussion of how many people in Bel Air had lost limbs. Then he would go from limbs to souls, to the number of people who had lost family - siblings, parents, children - and friends. These were the real ghosts, he would say, the phantom limbs, phantom minds, phantom loves that haunt us, because they were used, then abandoned, because they were desolate, because they were violent, because they were merciless, because they were out of choices, because they did not want to be driven away, because they were poor. (Danticat 2008, 113)
\end{abstract}

The magazine version ends on Tiye's telling the young radio producer: "You wanted to know what it's like for us,' he said. 'I just thought I'd give you a taste.”' (Danticat 2008, 113). The final sentence consists of Tiye's thinly veiled threat that he is not to worry: "As long as I'm here, nothing will happen to us tonight" (Danticat 2008, 113).

For Bernard, the attempt to change other people's lives for the better has turned into a threat to his own safety. By being implicated in a crime and being rescued by a gang later, he has not only been forced to give up his stance as an impartial observer - which might have been impossible to uphold in the first place - but is also at the mercy of someone whose power extends to being able to kill him, but not to keep him alive. Moreover, whatever fragile security he might have does not extend to the future. Tiye's promise is that nothing will happen "tonight." Danticat implies that a life that has been suspended from any temporality, and is trapped in the present, is devoid of any perspective, or hope.

In the magazine version of the story, Bernard will have no choice but to emigrate. ${ }^{10}$ In the novel, he is killed the very next day; his memory is obliterated by a report stating that he was just "[a]nother bandit [...] erased from the face of this earth" (Danticat 2013, 83); the cruel irony of the story is in the fact that Bernard himself would have been assigned to write this story, had he been alive, and he would have found a different moral than the one formulated in the official news; instead his original idea is stolen by another producer and changed beyond recognition to cater to a sensationalist audience.

10 In the novel, Bernard is betrayed by his lover, which adds to the novel's complexity at a later point. By contrast, his reliance on being rescued by his brother who lives in Canada in the magazine version is another indication that this is a cycle which can only be broken through some element of outside intervention by a deus ex machine. Bernard himself, while idealistic, cannot mobilise change from within. 
Danticat's narrative strategies are important in this respect: through the story's construction - and by using Bernard as a focaliser, she manages to fill a blank and recover a 'truth' from the inside of the slum, something which she then goes on to imply is not representable: even Bernard is ultimately cast as a problematic, and ethically dubious, observer. Yet, the question of Danticat's legitimacy as author, and thus owner, of the story remains debatable. As mentioned above, however, she is conscious of these problematic aspects and addresses them.

The way in which Danticat's approach differs from that of Junot Diaz becomes evident in two scenes in which they both write about those children given away to 'stay with another family,' in the hope of having better life chances but in reality often just ending up enslaved. The Haitian Creole term restavèk captures the idea of 'staying with someone'; the Dominican Creole term criada denotes, more literally, a servant. In Claire of the Sea Light, Claire's father is aware that her enslavement is a likely fate for his daughter but he hopes that she will be better off against all odds when he presents her to his neighbour, a fabric vendor:

While twirling for the lady, Claire heard her father say, 'I am for correcting children, but I am not for whipping.' He looked down at Claire and paused. His voice cracked, and he jabbed his thumb into the middle of his palm as he continued. 'I am for keeping her clean, as you can see. She should of course continue with her schooling, be brought as soon as possible to a doctor when she is sick.' (Danticat 2013, 7)

This arouses empathy with the father, who, in a stressed performance of naïveté, lays bare his powerlessness, which he attempts to mask, and his awareness that chances are slim that Claire will indeed have a better life. The neighbour answers the father, groaning "a warning, like an impossible word, a word she had no idea how to say. 'Why would you want your child to be my servant, a restavèk?"” (Danticat 2013, 8). The term embarrasses the father, who changes the subject. When Danticat uses a word in French Creole, she tends to give its English translation in direct succession. This underlines her status as intermediary who guides the reader, sometimes making her characters' dialogues sound less natural.

Junot Díaz's depiction has a different thrust. The Brief Wondrous Life of Oscar Wao is, among other things, the story of "ghetto nerd" and hopeless romantic Oscar. He falls in love with a prostitute in the Dominican Republic, which proves fatal for him. A section of the novel provides background to the story of Beli, Oscar's mother. When she is a young child, she is sold as a restavèk:

But most folks figured that [Beli's mother] had sold the girl [Beli] to some other family. Back then, as now, the buying and selling of children, common enough.

And that's exactly what happened. Like a character in one of Oscar's fantasy books, the orphan (who may or may not have been the object of a supernatural vendetta) was sold to 
complete strangers in another part of Azua. That's right - she was sold. Became a criada, a restavek. Lived anonymously among the poorest sectors on the Island, [...] and subsequently she was lost from sight for a long long time. (Díaz 2008, 253)

This is followed by a footnote, in which Yunior, the narrator, supplies complementary information - since there is no way to retrieve what happened in the gap of Beli's story, he talks about his own experience with a restavèk; Oscar's story revolves around the major gap of the protagonist himself missing from the text, Yunior's sole legitimacy to the story is his association with his girlfriend, Oscar's sister. In the episode about criadas, however, Yunior supplies it with his own firsthand account: Criadas are still a topical problem in the narrator's present, even though he is of a younger generation. The anecdote's moral stresses the inevitability of an all-powerful and inescapable vicious circle, which keeps reproducing itself:

I lived in Santo Domingo only until I was nine, and even I knew criadas. Two of them lived in the callejón behind our house, and these girls were the most demolished, overworked human beings I'd known at that time. One girl, Sobeida, did all the cooking, all the cleaning, fetched all the water, and took care of two infants for a family of eight - and chickie was only seven years old! She never went to school, and if my brother's first girlfriend, Yohana, hadn't taken the time - stolen behind her people's back - to teach her the ABCs, she wouldn't have known nada. Every year I came home from the States, it was the same thing; quiet hardworking Sobeida would stop in for a second to say a word to my abuelo and my mother (and also to watch a couple of minutes of a novela) before running off to finish her next chore [...] I tried to talk to her, of course - Mr. Community Activist - but she would skitter away from me and my stupid questions. What can you two talk about? my moms demanded. La pobrecita can’t even write her own name. And then when she was fifteen, one of the callejón idiots knocked her up, and now, my mother tells me, the family has got her kid working for them too, bringing in the water for his mother. (Díaz 2008, 253)

Yunior's ironic stance masks his own feeling of powerlessness and is represented by his taunting mother, and the ironical title "Mr. Community Activist." The narrator stands in for the reader who, with a similar impulse to help, has to realise that individual good-will is not necessarily enough to combat endemic structural failings.

The space between the main body of the text with Beli's story and the footnote detailing Sobeida's misfortune opens a gap of the un-representable. Narrative gaps are at the heart of the novel's poetics. The novel's most fundamental gap is, however, that of the missing protagonist Oscar, whose story the reader learns, but who has died and is therefore present only in the memory of the narrator. Other gaps that are alluded to are that of the original inhabitants of Hispaniola, who disappeared from "what Oscar, at the end, would call the Ground Zero of the New World" (Díaz 2008, 1), and also the disappeared, who were murdered 
during the Trujillo dictatorship. ${ }^{11}$ This hints at the fact that the narrator deems some things best to be left unrepresented - either because they simply cannot be recovered, or because one has a moral obligation to know them. The blank space thus opened is visualised on the actual page itself through the interplay of footnotes and main text. It also works through rhetorical strategies, especially through praeteritios, where the narrator evokes the very thing he claims not to be invoking. By drawing attention to the thing he claims to omit, he additionally emphasises the sense of blanks, gaps, and silences, which is also in keeping with Díaz's fascination with “how people 'un-see.' How societies are trained not to see," which he calls the "point of 'un-view"” (Miranda 2009, 29). Especially praeteritios are effective in unfamiliarising the familiar, and thus making visible what might not otherwise be noticed.

The following is a prototypical example of Díaz's strategy of writing about poverty. The original sentence, headed "Oscar goes native," stretches across four pages ${ }^{12}$ and discusses Oscar's return to the Dominican Republic, which is a central experience for the narrator too:

\begin{abstract}
After his initial homecoming week [...] he [Oscar] refused to succumb to that whisper that all long-term immigrants carry inside themselves, the whisper that says You Do Not Belong, [...] after he'd given out all his taxi money to beggars and had to call his cousin Pedro Pablo to pick him up, after he'd watched shirtless shoeless seven-year-olds fighting each other for the scraps he'd left on his plate at an outdoor café, [...] after a skeletal vieja grabbed both his hands and begged him for a penny, after his sister had said, You think that's bad, you should see the bateys, [...] after he'd taken a dump in a latrine and wiped his ass with a corn cob, - now that's entertainment, he wrote in his journal - after he'd gotten somewhat used to the surreal whirligig that was life in La Capital - the guaguas, the cops, the mind-boggling poverty, the Dunkin' Donuts, the beggars, the Haitians selling roasted peanuts at the intersections, the mind-boggling poverty, the asshole tourists hogging up all the beaches, the Xica da Silva novelas where homegirl got naked every five seconds that Lola and his female cousins were cracked on, the afternoon walks on the Conde, the mind-boggling poverty, the snarl of streets and rusting zinc shacks that were the barrios populares [...] Oscar fell in love with a semiretired puta. (Díaz 2008, 276-279)
\end{abstract}

There are more examples from Oscar Wao, which are often constructed in a similar manner: long sentences, written in a paratactic staccato, packed with

11 The comparison with Ground Zero has led other critics to read the novel as a 9/11 novel: Alberto S. Galindo, for example, reads the novel not as "about 9/11 per se," but as "conditioned by the political and cultural discursive practices after 9/11" (Galindo 2011, 82). This reading, while not entirely convincing, inadvertently points to the fact that the novel's strategic blanks and gaps invite to be interpretatively filled by its readers.

12 The entire sentence is 961 words long, with a parenthetical paragraph of 136 words (and with shorter sentences) inserted in between. 
polysyndetons and accumulations, highlight the confusion and disorientation that occurs when one arrives in an unfamiliar space. Anaphoras, while seemingly structuring the sentences on a temporal plane, thus making all elements equal, underline the disparate, and that which does not fit together, the incoherent: they put a 'welcome chaos' back into the picturesque. The imagery, however, while rendered in fresh words, is somewhat familiar. The reader's gaze is legitimated through the narrator's status of both insider and outsider. And following Walcott, it then becomes artistic: Not only do these scenes emulate how a visitor might experience the sight poverty in the Caribbean; they too hint towards something beyond the mere representation. Taken together, these fragments give the impression of a whole picture, which echoes Walcott's famous image of the broken vase, and constitute a way out for a colonised civilisation, which, as Édouard Glissant argued, does not dispose of a linear history (Artières and Glissant 2003).

Yunior is also the narrator in Díaz's linked short story collections Drown (1996) and This is How You Lose Her (2012). In the latter, he deploys a similar strategy when describing his coming home to Santo Domingo:13

\begin{abstract}
If this was another kind of story, I'd tell you about the sea [...] How when I'm driving in from the airport and see it like this, like shredded silver, I know I'm back for real. I'd tell you how many poor motherfuckers there are. More albinos, more cross-eyed niggers, more tígueres than you'll ever see [...] I'd tell you about the shanties and our no-running water faucets and the sambos on the billboards and the fact that my family house comes equipped with an ever-reliable latrine [...] I'd tell you about the street where I was born, Calle XXI, how it hasn't decided yet if it wants to be a slum or not and how it's been in this state of indecision for years.
\end{abstract}

But that would make it another kind of story, and I'm having enough trouble with this one as it is. You'll have to take my word for it. Santo Domingo is Santo Domingo. Let's pretend we all know what goes on there. (Díaz 2012, 9-10)

Ostensibly, the narrator throws his hands in the air and can only declare that "Santo Domingo is Santo Domingo," that signifier and signified collapse into one, and can only be grasped if they equal each other, which renders the linguistic sign representing reality incomprehensible, since its being blown up strips it of all meaning-generating abstractions: this invokes the famous Borgesian map, which only becomes sufficiently detailed once it reaches the size of the territory it details; ironically, the details that the narrator mentions do, collectively, contribute to an image that is recognisable to a reader. While in This is How You Lose Her the narrator-focaliser pretends to give up in the face of the

13 The two original short stories were published within two years (in 1998 and 2000) in The New Yorker, which might help towards explaining their stylistic similarities. 
task of representation, he does of course continue to represent the reality that surrounds him (albeit in a 'different kind of story'): Yunior takes on the role of a tourist guide. Legitimated by origin and birth, and by his familiarity with both the Dominican Republic and the US, he can cross from one space to the other, performing signs of a mild culture shock, but recovering quickly. ${ }^{14}$ And unlike a 'regular' tourist guide, he seems to challenge readers. He makes them recognise their obligation to know certain facts of life, and if not, to go and read up on them, or, at least to play along at seemingly being informed, thus sparing the narrator the trouble of representing the un-representable. The obligation to know is also reflected at the word level: Díaz's narrator is more uncompromising in his use of Spanish words and a broad range of high and pop-cultural references, from 'high' literature to Science Fiction: This implies that just as one would not explain terms from Greek mythology, these references form part of a cosmopolitan thesaurus; by not being explained - and thus not othered - they are to be part of a reader's cultural capital.

However, the narrator's seemingly flippant remark about the 'other kind of story' that he is unwilling - or unable - to tell means more than the narrator casually preferring a love story over a social-realist one. It's a definition of Díaz's own poetics. In an interview, he affirms that

exposing our racisms, etc., accurately has never seemed to be enough; the problem with faithful representations is that they run the risk of being mere titillation or sensationalism. In my books, I try to show how these oppressive paradigms work together with the social reality of the characters to undermine the very dreams the characters have for themselves. So, Yunior thinks $\mathrm{X}$ and $\mathrm{Y}$ about people and that logic is, in part, what fucks him up. Now if the redounding is too blunt and obvious, then what you get is a moralistic parable and not literature. But, if it's done well, then you get both the ugliness that comes out of showing how people really are around issues like race and gender, but also a hidden underlying counter-current that puts in front of you the very real, very personal, consequences of these orientations. (Moya 2012, n. pag.)

He renounces a naturalist or merely documentary mode as unliterary. More so, mere representation is not interesting, and limits fiction's appeal to a potentially broader audience: given that people already "spend a lot of time being colonized" (Céspedes et al. 2000, 896), they do

not want scholarly treatises for forty, fifty pages. What they wanted was a story that made sense to them, that kept them awake [...] keeping those guys awake was a tough thing to do

14 In passing, Díaz also persiflages the notion of the Caribbean-as-paradise: "I'm in heaven, [Oscar] wrote in his journal. //Heaven? His cousin Pedro Pablo sucked his teeth with exaggerated disdain. Esto aquí es un maldito infierno" (Díaz 2012, 275). 
and also to have intellectual payloads and artistic payloads that you want to deliver [...] My friends have the shortest attention span. They don't want to hear nonsense. (Céspedes et al. 2000, 903)

Another gap which runs through the novel is that of the split between instances of poverty in the industrialised world and in the Global South. This gap represents a parallax, or two mutually exclusive perspectives on the same thing. The parallax, popularised by Slavoj Žižek in recent years, means

\begin{abstract}
putting two incompatible phenomena on the same level [...] [and] is strictly analogous to what Kant called 'transcendental illusion,' the illusion of being able to use the same language for phenomena which are mutually untranslatable and can be grasped only in a kind of parallax view, constantly shifting perspective between two points between which no synthesis or mediation is possible. Thus there is no rapport between the two levels, no shared space - although they are closely connected, even identical in a way, they are, as it were, on the opposed sides of a Moebius strip. (Žižek 2006, 4)
\end{abstract}

Oscar is therefore the focaliser of two different forms of poverty: that which he sees - more or less as a tourist in the Dominican Republic, and that which he experiences as the son of a single working mother in Patterson, New Jersey. The latter poverty is a form which is in a sense less existential, and it is only one among several kinds of marginalisation which Oscar faces: he is kind of poor, kind of a nerd, perceived as kind of gay, and kind of a Latino.

Whereas Edwidge Danticat records this split through the autobiographical weight, and authentic but self-questioning voice of her writing, Junot Díaz's narrator tackles it with the help of rhetorical figures and intertextual references. These are attempts to make the unrepresentable manageable, while still carrying an emotional force. Beneath the wordly-wise and detached veneer of the butch narrator a vulnerable and deeply humanist character is hiding. Where necessary, Díaz and Danticat deploy the imagery of the picturesque. More often than not, however, they represent poverty through a conscious choice of gaps. In an application of Wolfgang Iser's reader-response theory, it is in these very blanks, and through the readers' filling them, that the work of art comes into being (cf. Iser 1994). ${ }^{15}$ And the work of art is that which, according to Derek Walcott and Junot Díaz, is legitimately putting the picturesque back into the depiction of poverty.

15 Robert C. Holub, surveying Iser's theoretical work, puts it like this: “The blanks and vacancies thus chart a course for reading a text by organizing the reader's participation with their structure of shifting positions. At the same time they compel the reader to complete the structure and thereby produce the aesthetic object" (Holub 1984, 94). 
Even literary fiction is, however, part of a marketplace. The question is therefore whether it is any more legitimate to 'sell the Caribbean' literarily rather than literally, and whether literary slumming is any 'better' than an actual visit. The argument that documentary accounts written by inhabitants of a slum give them a voice might not hold true: once a story has been put out, they do not have control over it any longer, like Pascal in Claire of the Sea Light, whose story project was stolen even before he started it. Morever, Junot Díaz and Edwidge Danticat, albeit both having a history of social mobility, do not write first-hand accounts of life in slums, and their work cannot be reduced to this aspect. However, the stories they tell enable readers to identify with certain characters, giving them a more differentiated and empathetic view on, for example, stories of violence, and those whose individuality disappears behind ascriptions such as 'criminal.' Moreover, where in reality it would be hard to look away, both Díaz and Danticat use strategies to divert the readers' gaze where representation meets its ethical or narrative limits.

As has been argued in recent years, the value of fiction can also be practical: there is a kind of developmental knowledge inherent in fiction that cannot quite be captured by other forms of representation, e.g., statistical data (for a detailed discussion of this, see Lewis et al. 2008). However, as Claire Williams notes, "it is impossible not to be a voyeur when writing about an alien environment, no matter how integrated one becomes or how generous one's intentions are" (Williams 2008, 498), and nobody travelling to a slum - be it physically or through a text - can escape this role. Yet, William concedes with reference to John Hutnyk that a literary slum tour has the potential "to insert new and disruptive rumours into the circuits of truth-illusion that maintain complacency" (Hutnyk 1996, 223), and to thus initiate change for the better. Importantly, this potential hinges on the text's ideological configuration, and on the way the latter plays itself out in the act of reading: it means selling the Caribbean for a good cause, and without giving it away.

\section{Works Cited}

Artières, Philippe and Édouard Glissant (2003). “'Solitaire et solidaire.' Entretien avec Edouard Glissant.” Terrain-Revue d'ethnologie de l'Europe 41. September, 9-14.

Céspedes, Diógenes, Silvio Torres-Saillant and Junot Díaz (2000). "Fiction is the Poor Man's Cinema: An Interview with Junot Díaz." Callaloo 23.3, 892-907.

Danticat, Edwidge (2008). "Ghosts.” The New Yorker. November 24, 108-113.

Danticat, Edwidge (2010). Create Dangerously: The Immigrant Artist at Work. Princeton, NJ:

Princeton University Press. 
Danticat, Edwidge (2013). Claire of the Sea Light. New York, NY: Alfred A. Knopf.

Díaz, Junot (2008). The Brief Wondrous Life of Oscar Wao. London: Faber and Faber.

Díaz, Junot (2012). This Is How You Lose Her. London: Faber and Faber.

Dürr, Eveline and Rivke Jaffe (2012). "Theorizing Slum Tourism: Performing, Negotiating and Transforming Inequality." European Review of Latin American and Caribbean Studies 93, 113-123.

Galindo, Alberto S. (2011). "Less 9/11 is More 9/11: The Brief Wondrous Life of Oscar Wao and A Day a Night and a Day." Cultura, lenguaje y representación/Culture, Language and Representation 9, 81-97.

Handley, George and Derek Walcott (2005). “'The Argument of the Outboard Motor': An Interview with Derek Walcott.” Elizabeth DeLoughrey, Renée Gosson and George Handley, eds. Caribbean Literature and the Environment: Between Nature and Culture. Charlottesville, VA: University of Virginia Press, 127-139.

Hawthorne, Evelyn (2003). “Jamaica Kincaid's Politics of Voice.” Journal of West Indian Literature 11.2, 1-28.

Holub, Robert C. (1984). Reception Theory: A Critical Introduction. London and New York, NY: Routledge.

Hutnyk, John (1996). The Rumour of Calcutta: Tourism, Charity and the Poverty of Representation. London: Zed Books.

Iser, Wolfgang (1994). "Die Appellstruktur der Texte.” Rezeptionsästhetik. München: UTB, 228-252.

Kobo Town (2013). “Postcard Poverty.” Jumbie in the Jukebox. Compact Disk. Cumbancha/ Indigo.

Korte, Barbara and Georg Zipp (2014). Poverty in Contemporary Literature: Themes and Figurations on the British Book Market. Basingstoke and New York, NY: Palgrave Macmillan.

Kumar, Krishan (1995). "Versions of the Pastoral: Poverty and the Poor in English Fiction from the 1840 s to the 1950s." Journal of Historical Sociology 8.1, 1-35.

Lanchester, John (2014). How to Speak Money: What the Money People Say and What They Really Mean. London: Faber and Faber.

Lewis, David, Dennis Rodgers and Michael Woolcock (2008). "The Fiction of Development: Literary Representation as a Source of Authoritative Knowledge." Journal of Development Studies 44.2, 198-216.

McCaulay, Diana (2010). Dog-Heart. Leeds: Peepal Tree Press.

Miranda, Katherine (2009). "Junot Díaz, Diaspora, and Redemption: Creating Progressive Imaginaries." Sargasso, Quísqueya: La República Extended 2008-2009.II, 23-39.

Moya, Paula M.L. (2012). “The Search for Decolonial Love: An Interview with Junot Díaz.” Boston Review. June 26. <http://bostonreview.net/books-ideas/paula-ml-moya-decolonial-loveinterview-junot-d\%C3\%ADaz> (December 12, 2014).

Powell, Richard J. (2008). “The Picturesque, Miss Nottage and the Caribbean Sublime." Small Axe 25, 157-168.

Selinger, Evan and Kevin Outterson (2009). “The Ethics of Poverty Tourism.” Boston University School of Law Working Paper 09-29. Boston, MA. <http://www.bu.edu/law/faculty/ scholarship/workingpapers/Selinger-Outterson-PovertyTourism.html $>$ (December 12, 2014).

Strachan, Ian G. (2002). Paradise and Plantation: Tourism and Culture in the Anglophone Caribbean. Charlottesville, VA: University of Virginia Press. 
Thompson, Krista A. (2006). An Eye for the Tropics: Tourism, Photography, and Framing the

Caribbean Picturesque. Durham, NC: Duke University Press.

Trow, George W.S. (1974). "Two Gatherings.” The New Yorker. March 25, 31-32.

Walcott, Derek. (1971). "What the Twilight Says: An Overture." Dream on Monkey Mountain and

Other Plays. New York, NY: Farrar, Straus and Giroux, 3-40.

Walcott, Derek. (1990). Omeros. New York, NY: Farrar, Straus and Giroux.

Walcott, Derek. (1998). "The Antilles: Fragments of Epic Memory." What the Twilight Says:

Essays. New York, NY: Farrar, Straus and Giroux, 65-84.

Walrond, Eric (1926). Tropic Death. New York, NY: Boni and Liveright.

Williams, Claire (2008). "Ghettotourism and Voyeurism, or Challenging Stereotypes and Raising Consciousness? Literary and Non-Literary Forays into the Favelas of Rio de Janeiro." Bulletin of Latin American Research 27.4, 483-500.

Žižek, Slavoj (2006). The Parallax View. Cambridge, MA: MIT Press. 